\title{
MODELLING OF ELECTRIC FIELDS IN AXISYMMETRIC SYSTEMS FOR CATHODE PROTECTION OF UNDERGROUND STRUCTURES
}

\author{
T.M. Shamsutdinova, Bashkir State Agrarian University, Ufa, Russian Federation, \\ tsham@rambler.ru
}

The aim of this work is to carry out numerical calculation of electric fields in axisymmetric systems for cathode protection of underground structures against corrosion. As is known, cathode protection is a complex multi-parameter system, which has a number of features depending on the type and form of the protected structure, properties of the surrounding environment, etc. As a result, the modelling of protection parameters is quite complex and requires new more advanced computer technologies. In this work, we construct a mathematical model of the problem on the electric field distribution in an axisymmetric system for cathode electrochemical protection of underground structures. In addition, we propose an algorithm to solve the problem. The algorithm is based on the use of integral Green transformations and, in particular, the second Green integral formula. Also, we give an example of a computer implementation of the proposed algorithm in the case of a homogeneous half-space. The Scilab application package is used to implement the example.

Keywords: mathematical modelling; cathodic protection; electric field; Green integral formula; Scilab.

\section{Introduction}

Protection of underground structures against corrosion is one of the most important measures to preserve the operational characteristics of these objects. Cathodic electrochemical protection allows to slow down the corrosion processes due to changes in the electrical potential of the protected structure surface that is carried out using an external DC source. Among the possible problems we note the risk of partial destruction of the insulation coatings of protected structures, as well as the impact of the so-called stray currents on nearby objects. Therefore, the problem on mathematical modelling of the electrochemical system parameters is relevant [1-3 and others].

Theoretical and practical issues of modelling electric fields in systems for electrochemical cathode protection are considered in the fundamental works by Iossel Yu.A., Glazov N.P., Ivanov V.T., Ostapenko V.N., Cikerman L.Ya., Tkachenko V.N., Krasnoyarskii V.V., Lortkipanidze B.G., Pritula V.A., Freyman L.I. and others. These works propose various mathematical models of the distribution of electric fields in electrochemical systems, and consider numerical and analytical methods to solve the issues. However, it cannot be said that this issue is fully resolved. Cathodic protection is a complex multi-parameter system, which has a number of features depending on the type and form of the protected structure, properties of the soil that surrounds the structure, etc. As a result, the modelling of protection parameters is quite complex and requires new more advanced computer technologies. 


\section{Mathematical Model of the Electric Field in the Axisymmetric System for Cathode Protection of Underground Structures}

Consider cathode electrochemical protection of an axisymmetric underground structure located in a layered half-space. We assume that the half-space consists of $N$ axisymmetric layers $\Omega_{i}$ with specific electrical conductivities $\sigma_{i}$, where $i \in$ $\{1, \ldots, N\}$. Let $I$ be the current flowing down from the anode ground located at the point $A$ of the layer $\Omega_{i_{0}} ; u_{i}$ be the value of potential in the layer $\Omega_{i}$, and $k$ be the number of the layer $\Omega_{k}$ in which the protected structure is located. For calculations, we use cylindrical coordinate system $(r, \varphi, z)$ and assume that the symmetry axis of the environment coincides with the symmetry axis of the structure (Fig. 1).

Based on the general theory for

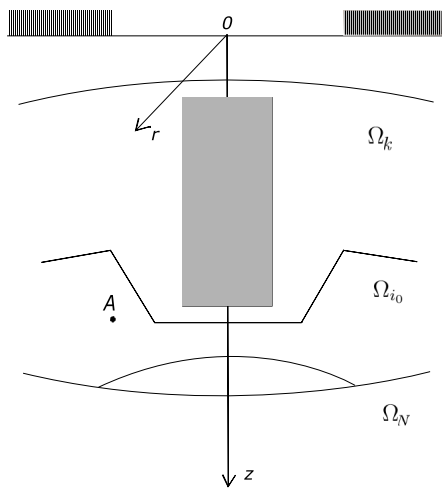

Fig. 1. General scheme of the electrochemical system modelling of electric fields of a point source in inhomogeneous environment [4-5], we obtain mathematical model (1) - (8) for cathode protection of axisymmetric underground structures:

$$
\begin{aligned}
& L u_{i}=\frac{\partial^{2} u_{i}}{\partial r^{2}}+\frac{1}{r} \frac{\partial u_{i}}{\partial r}+\frac{1}{r^{2}} \frac{\partial^{2} u_{i}}{\partial \varphi^{2}}+\frac{\partial^{2} u_{i}}{\partial z^{2}}=0, \quad(r, \varphi, z) \in \Omega_{i}, \quad i \neq i_{0}, \\
& L u_{i_{0}}=-\frac{I}{r_{0} \sigma_{i_{0}}} \delta\left(r-r_{0}\right) \delta(\varphi) \delta\left(z-z_{0}\right), \quad(r, \varphi, z) \in \Omega_{i_{0}}, \\
& \left.\frac{\partial u_{i}}{\partial z}\right|_{z=0}=0, \quad i \in M_{1} \\
& \left.u_{i}\right|_{f_{i}(r, z)=0}=\left.u_{i+1}\right|_{f_{i}(r, z)=0}, \\
& \left.\sigma_{i} \frac{\partial u_{i}}{\partial n}\right|_{f_{i}(r, z)=0}+\left.\sigma_{i+1} \frac{\partial u_{i+1}}{\partial n}\right|_{f_{i}(r, z)=0}=0, \quad i=1, \ldots, N-1 \text {, } \\
& u_{k}+\left.c(r, z) \sigma_{k} \frac{\partial u_{k}}{\partial \vec{n}_{S}}\right|_{S}=v(r, \varphi, z), \\
& \left.\frac{\partial u_{i}}{\partial \varphi}\right|_{\varphi=0}=0,\left.\quad \frac{\partial u_{i}}{\partial \varphi}\right|_{\varphi=\pi}=0, \quad-\infty<z<\infty, \quad 0<r<\infty, \quad i=1, \ldots, N, \\
& u_{i} \rightarrow 0, \quad \sqrt{r^{2}+z^{2}} \rightarrow \infty, \quad i \in M_{2}, \\
& \left|u_{p}\right|<\infty, \quad \sqrt{r^{2}+z^{2}} \rightarrow 0
\end{aligned}
$$

where $\delta$ is the Dirac delta function, $M_{1}$ is a set of indices of layers that are beside the earth surface, $M_{2}$ is a set of indices of layers that tend to infinity, $f_{i}(r, z)$ are equations describing the boundaries between layers that are axially symmetric, $i \in\{1, \ldots, N\}$; $\vec{n}$ is the normal to the boundary between the corresponding layers, $S$ is the protected structure surface, $c(r, z)$ is the function of the specific polarizability of the protected structure surface, $v(r, \varphi, z)$ is the function describing the distribution of the potential of the inner 
coating of the double electric layer at the boundary between the structure and surrounding environment, $\vec{n}_{S}$ is the external normal to the structure surface.

In this case, equations (1) - (2) characterize the anode grounding field with coordinates $\left(r_{0}, 0, z_{0}\right)$, equation (3) describes the electric field on the earth surface, (4) - (5) present conditions of continuity of potential at the boundary between layers, (6) is the boundary condition on the protected structure surface, $(7)$ is the condition of symmetry of the electric field relative to the plane $(\varphi=0, \varphi=\pi, z),(8)$ is both the condition of the potential drop at the infinite distance from the field source and the condition that the potential is limited in some layer with the number $p$.

\section{Development of an Algorithm to Solve the Problem}

Since the electric field is symmetrical with respect to the variable $\varphi$, then the dimension of problem statement (1) - (8) can be reduced by applying the Fourier transform

$$
\bar{u}^{(m)}(r, z)=\int_{0}^{\pi} u(r, \varphi, z) \cos (m \varphi) d \varphi
$$

where the functions $\bar{u}^{(m)}(r, z)$ are coefficients of the expansion of the function $u(r, \varphi, z)$ in the Fourier series

$$
u(r, \varphi, z)=\frac{1}{\pi} \bar{u}^{(0)}(r, z)+\frac{2}{\pi} \sum_{m=1}^{\infty} \bar{u}^{(m)}(r, z) \cos (m \varphi) .
$$

Next, we use the second Green integral formula [6], according to which the following equality holds for the desired formula $\bar{u}^{(m)}(r, z)$ and some Green function $G$ :

$$
\iint_{\Omega}(G L \bar{u}-\bar{u} L G) d \Omega=\int_{\Gamma}\left(G \frac{\partial \bar{u}}{\partial \vec{n}}-\bar{u} \frac{\partial G}{\partial \vec{n}}\right) d \gamma
$$

where $\Gamma$ is the set of all integration boundaries (i.e., boundaries between layers) $\gamma_{i}$, where $i \in\{1, \ldots, N-1\}$. We assume that the Green function can be found analytically or numerically, and the $m$-th coefficients of the expansion of the Green function in a Fourier series satisfy the equations

$$
\begin{gathered}
\frac{\partial^{2} G_{i}^{(m)}}{\partial r^{2}}+\frac{1}{r} \frac{\partial G_{i}^{(m)}}{\partial r}+\frac{\partial^{2} G_{i}^{(m)}}{\partial z^{2}}-\frac{m^{2}}{r^{2}} G_{i}^{(m)}=-\frac{1}{r_{q}} \delta\left(r-r_{q}\right) \delta\left(z-z_{q}\right), \\
G_{k}^{(m)}+\left.c(r, z) \sigma_{k} \frac{\partial G_{k}^{(m)}}{\partial \vec{n}_{S}}\right|_{S}=0 .
\end{gathered}
$$

Here the boundary conditions similar to conditions $(3)-(5),(8)$ are satisfied.

Use Green formula (11) for each integration domain and summarize the obtained results. For each fixed value $m=0,1,2, \ldots$, we obtain that the initial boundary value problem is reduced to the Fredholm integral equation of the second kind relative to the corresponding $m$-th coefficient of the expansion of the current density $j^{(m)}(r, z)$ in the Fourier series

$$
c(P) j^{(m)}(P)=-2 \int \frac{j^{(m)}(Q)}{\sigma_{k}} r_{q}\left(G^{(m)}(P, Q)+c(Q) \sigma_{k} \frac{\partial G^{(m)}(P, Q)}{\partial \vec{n}_{q}}\right) d \gamma_{q}+
$$




$$
+2 \int_{\gamma} r_{q} \bar{v}^{(m)}(Q) \frac{\partial G^{(m)}(P, Q)}{\partial \vec{n}_{q}} d \gamma_{q}-\frac{I}{\sigma_{i_{0}}} G^{(m)}(P, A)+\bar{v}^{(m)}(P),
$$

where $Q$ is the integration variable, $P$ is the projection of the calculation point onto the plane $(r, 0, z) ; A$ is the projection of the point containing the anode ground; $\vec{n}_{q}$ is the external normal to the structure surface at the point $Q ; \gamma$ is the generator of the protected structure surface; the function $j^{(m)}(r, z)$ is defined as follows:

$$
j^{(m)}(r, z)=\left.\sigma_{k} \frac{\partial \bar{u}^{(m)}(r, z)}{\partial \vec{n}}\right|_{\gamma} .
$$

Further, from (6), (14) and (15), we find that the value of the function $\bar{u}^{(m)}$ can be calculated by the formulas

$$
\begin{gathered}
\bar{u}^{(m)}(P)=\int_{\gamma} \frac{j^{(m)}(Q)}{\sigma_{k}} r_{q}\left(G^{(m)}(P, Q)+c(Q) \sigma_{k} \frac{\partial G^{(m)}(P, Q)}{\partial \vec{n}_{q}}\right) d \gamma_{q}- \\
-\int_{\gamma} r_{q} \bar{v}^{(m)}(Q) \frac{\partial G^{(m)}(P, Q)}{\partial \vec{n}_{q}} d \gamma_{q}+\frac{I}{2 \sigma_{i_{0}}} G^{(m)}(P, A), \quad P \notin \gamma, \\
\bar{u}^{(m)}(P)=\bar{v}^{(m)}(P)-c(P) j^{(m)}(P), \quad P \in \gamma .
\end{gathered}
$$

The coefficients $\bar{u}^{(m)}$ of the expansion of the function $u$ in a Fourier series allow to determine the original form of the function $u$ by formula (10). In such a way we obtain the desired solution to the problem.

Therefore, we can formulate the final algorithm to solve problem (1) - (8) for each point of the computational domain.

1. Set the initial value of the iteration to be $m=0$.

2. Numerically solve Fredholm integral equation (14) with respect to the unknown current density $j^{(m)}(r, z)$ for the given fixed $m$.

3. Use formulas $(16)-(17)$ in order to calculate the value of the $m$-th coefficient $\bar{u}^{(m)}(r, z)$ of the expansion of the potential function $u(r, \varphi, z)$ in a Fourier series.

4. Calculate the potential function $u(r, \varphi, z)$ according to formula (10) by adding the next term of the form $\bar{u}^{(m)}(r, z)$. Verify the condition of termination of iterations (the achievement of a given calculating accuracy $\varepsilon$ ). If the specified accuracy is achieved, then stop the calculation. Otherwise, go to the next iteration with $m=m+1$ and repeat Steps $2-4$.

The general scheme to solve problem (1) - (8) is shown in Fig. 2.

Remark 1. An individual issue of this algorithm is the question on constructing the Green function for a layered half-space. The Green function $G$ is constructed in a certain analytical or numerically analytical way for each type of a specific computational domain.

As is known [7], the $m$-th term of the expansion of the Green function in a Fourier series for a homogeneous half-space is described as follows:

$$
G^{(m)}\left(r, z, r_{0}, z_{0}\right)=\frac{1}{2} \int_{0}^{\infty} e^{-a\left|z-z_{0}\right|} J_{m}(a r) J_{m}\left(a r_{0}\right) d a,
$$

where $J_{m}$ is the Bessel function of the first kind of the $m$-th order, $m=0,1,2, \ldots$. 


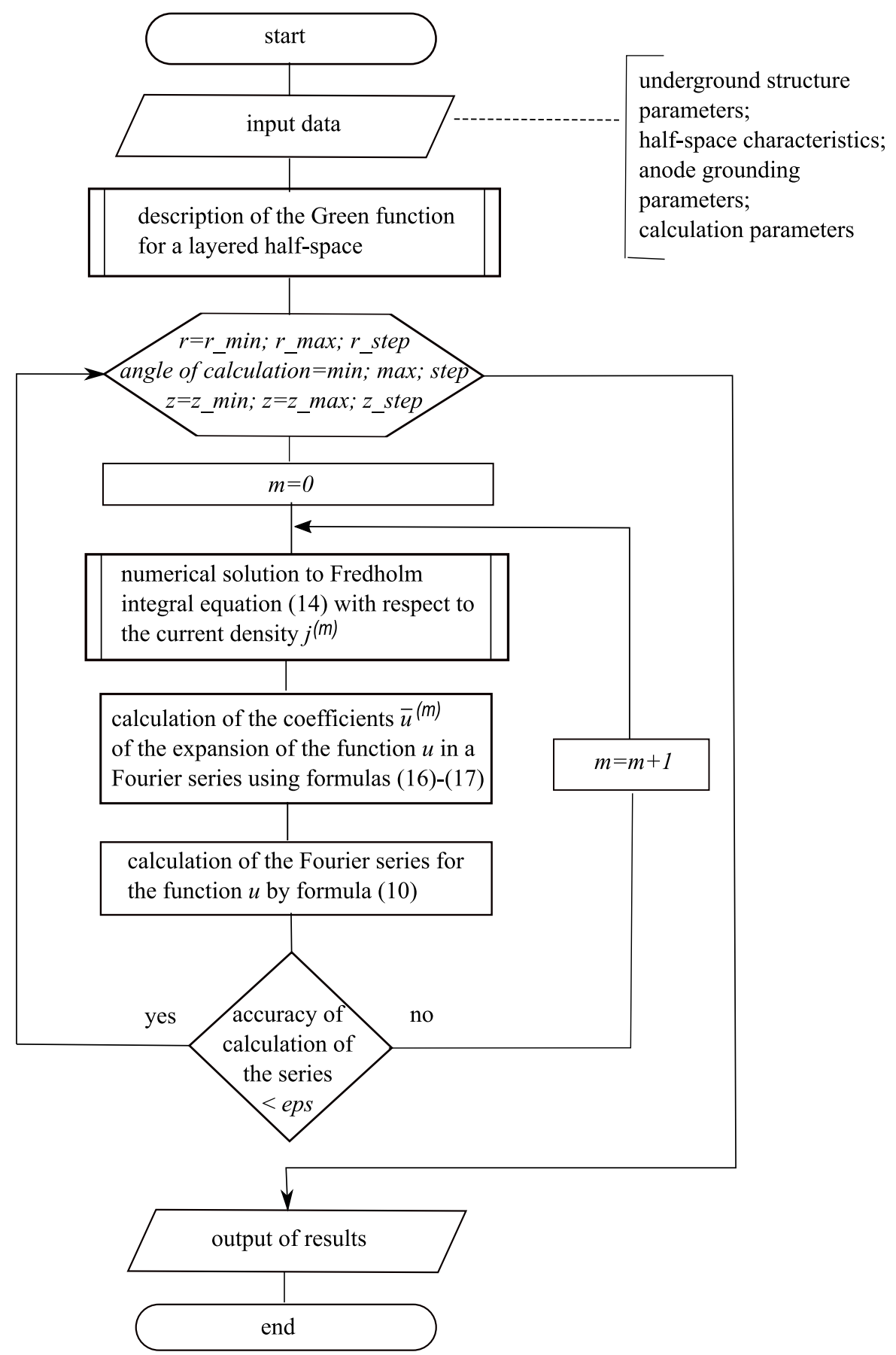

Fig. 2. Block diagram of the algorithm to solve the problem

An example of constructing the Green function for horizontally layered computational areas is given, for example, in [4]; examples for cylindrically layered and spherically layered areas are presented in $[8,9]$.

Remark 2. Another important issue is the problem on numerical solution to Fredholm integral equation of the second kind (14) with respect to the unknown value of the current density $j^{(m)}(r, z)$. In particular, one of the possible methods to solve this problem is the Krylov-Bogolyubov quadrature method [10], which allows to reduce the integral equation to a system of linear algebraic equations. In this case, the transformation of the 
integral equation is carried out by replacing the integral included in the equation with its approximate value of the integral sum. Derivatives along the normal to the structure surface can be found numerically by various numerical differentiation formulas.

\section{An Example of a Computer Implementation of the Algorithm in the Scilab Package in the Case of a Homogeneous Half-Space}

Numerical and software implementation of the algorithm given by formulas (10), (14) - (17) is a rather complicated problem and is possible only in a number of special cases, since, for arbitrary layers, the Green function is given in an implicit form.

In particular, as an example, consider the case of a homogeneous half-space under the following three assumptions. First, the considered half-space is homogeneous. Second, the condition $v(r, \varphi, z)=0$ is fulfilled. Third, the specific polarizability function $c(r, z)$ of the protected structure is such that the first term on the right-hand side of equation (16) is 0 . In this particular case, equations (16), (17) take the following form:

$$
\begin{aligned}
& \bar{u}^{(m)}(r, z)=\frac{I}{2 \sigma_{1}} G^{(m)}(P, A), \quad P \notin \gamma, \\
& \bar{u}^{(m)}(r, z)=\frac{I}{\sigma_{1}} G^{(m)}(P, A), \quad P \in \gamma .
\end{aligned}
$$

As noted above, in the case of a homogeneous half-space, the Green function takes well-known form (18).

In order to obtain a numerical solution to system of equations (10), (18) - (20), we use the Scilab application package, which allows to integrate functions numerically and to calculate complex composite mathematical expressions, including those that require to use built-in Bessel functions.

We use the tools of the Scilab package in order to develop a program for calculating and graphing data visualization for the electric field of a point source in the case of cathodic electrochemical protection of an underground spherical reservoir having the radius $r_{S}$ and the center located at the depth $z_{S} \mathrm{~m}$. The results of calculation of the electric field are presented in Fig. 3. In the calculations, we use the following numerical parameters: $I=2$ A, $\sigma_{1}=0,1$ Siemens $/ \mathrm{m}, v=0 \mathrm{~B}, r_{0}=4,5 \mathrm{~m}, z_{0}=4,5 \mathrm{~m}, r_{S}=2,5 \mathrm{~m}, z_{S}=4,5 \mathrm{~m}$, $\varphi=0$; calculated area is $r \in[0 ; 7] \mathrm{m}, z \in[1 ; 7] \mathrm{m}$.

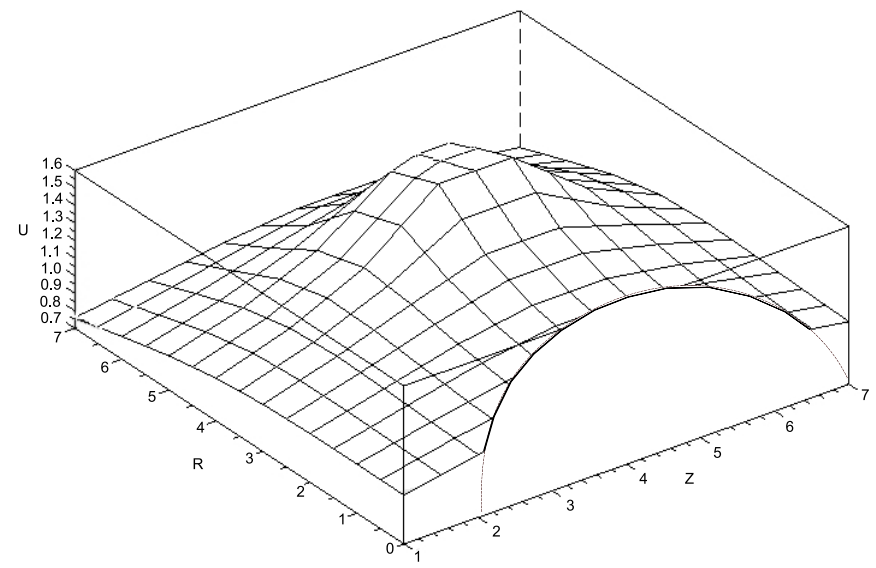

Fig. 3. Results of calculation of the distribution of the electric field 


\section{Conclusion}

In this work, we develop a mathematical model of problem on the distribution of an electric field in an axisymmetric system of cathode electrochemical protection of underground structures. In addition, we propose an algorithm to solve this problem. The algorithm is based on the use of integral Green transformations and, in particular, the second Green integral formula. Also, we give an example of a software implementation of this algorithm in the case of a homogeneous half-space. The Scilab application package was used to implement the example.

\section{References}

1. Taylor C.D. Corrosion Informatics: An Integrated Approach to Modelling Corrosion. Corrosion Engineering, Science and Technology, 2015, vol. 50, no. 7, pp. 490-508. DOI: $10.1179 / 1743278215 Y .0000000012$

2. Hameed K.W., Yaro A.S., Khadom A.A. Mathematical Model for Cathodic Protection in a Steel-Saline Water System. Journal of Taibah University for Science, 2016, vol. 10, no. 1, pp. 64-69. DOI: 10.1016/j.jtusci.2015.04.002

3. Bolotnov A.M., Bashaev M.A., Hisametdinov F.Z. [Interval Calculations in the Algorithms for Calculating the Electric Fields of Cathodic Protection of Main Pipelines]. Sistemy upravlenija i informacionnye tehnologii [Management Systems and Information Technology], 2015, vol. 62, no. 4, pp. 71-74. (in Russian)

4. Dmitriev V.I. [The General Method of Calculating the Electromagnetic Field in a Layered Medium]. Vychislitel'nye metody i programmirovanie [Computational Methods and Programming], 1968, no. 10, pp. 55-65. (in Russian)

5. Ostapenko V.N., Lukovich V.V., Kolesnik T.V., Kohanovskij I.N. Metody rascheta katodnoy zashhity metallicheskih sooruzheniy ot korrozii [Methods for Calculating the Cathodic Protection of Metal Structures against Corrosion]. Kiev, Naukova Dumka, 1966. (in Russian)

6. Tihonov A.N., Samarskii A.A. Uravneniya matematicheskoy fiziki [Equations of Mathematical Physics]. Moscow, Nauka, 1977. (in Russian)

7. Dmitriev V.I., Zaharov E.V. Integral'nye uravneniya $v$ kraevyh zadachah elektrodinamiki [Integral Equations in Boundary Problems of Electrodynamics]. Moscow, MSU, 1987. (in Russian)

8. Ivanov V.T., Yakovleva T.M. A Method for Calculating the Electric Field in a Cylindrically Layered Medium from a Point Source. Izvestiya. Physics of the Solid Earth, 1997, vol. 33, no. 10, pp. 859-861.

9. Ivanov V.T., Yakovleva T.M. Mathematical Modelling of Electric Fields in Electrochemical Protection Systems in Stratified Media. Russian Journal of Electrochemistry, 1996, vol. 32, no. 10, pp. 1133-1139.

10. Kantorovich L.V., Krylov V.I. Priblizhennye metody vysshego analiza [Approximate Methods of Higher Analysis]. Moscow, Leningrad, Fizmatgiz, 1962. (in Russian)

Received February 12, 2019 


\section{МОДЕЛИРОВАНИЕ ЭЛЕКТРИЧЕСКИХ ПОЛЕЙ В ОСЕСИММЕТРИЧНЫХ СИСТЕМАХ КАТОДНОЙ ЗАЩИТЫ ПОДЗЕМНЫХ СООРУЖЕНИЙ}

T.M. Шамсутдинова, Башкирский государственный аграрный университет, г. Уфа, Российская Федерация

Цель работы - проведение численных расчетов электрических полей в осесимметричных системах катодной защиты подземных сооружений от коррозии. Как известно, катодная защита является сложной многопараметрической системой, имеющей ряд особенностей в зависимости от вида и формы защищаемого сооружения, свойств окружающей сооружение среды и т.д. Все это делает процесс моделирования параметров защиты достаточно сложным, требующим все новых компьютерных технологий. В ходе работы была построена математическая модель задачи распределения электрического поля в осесимметричной системе катодной электрохимической защиты подземных сооружений. Далее предложен алгоритм решения данной задачи, основанный на применении интегральных преобразований Грина и, в частности, второй интегральной формулы Грина. Также приводится пример компьютерной реализации данного алгоритма в случае однородного полупространства. Для реализации примера был использован пакет прикладных программ Scilab.

Ключевые слова: математическое моделирование; катодная защита; электрическое поле; интегральная формула Грина; Scilab.

\section{Литература}

1. Taylor, C.D. Corrosion Informatics: An Integrated Approach to Modelling Corrosion / C.D. Taylor // Corrosion Engineering, Science and Technology. - 2015. - V. 50, № 7. P. $490-508$.

2. Hameed, K.W. Mathematical Model for Cathodic Protection in a Steel-Saline Water System / K.W. Hameed, A.S. Yaro, A.A. Khadom // Journal of Taibah University for Science. 2016. - V. 10, № 1. - P. 64-69.

3. Болотнов, А.М. Интервальные вычисления в алгоритмах расчета электрических полей катодной защиты магистральных трубопроводов / А.М. Болотнов, М.А. Башаев, Ф.З. Хисаметдинов // Системы управления и информационные технологии. - 2015. Т. 62 , № 4 . - С. $71-74$.

4. Дмитриев, В.И. Общий метод расчета электромагнитного поля в слоистой среде / В.И. Дмитриев // Вычислительные методы и программирование. - 1968. - № 10. C. $55-65$.

5. Остапенко, В.Н. Методы расчета катодной защиты металлических сооружений от коррозии / В.Н. Остапенко, В.В. Лукович, Т.В. Колесник и др. - Киев: Наукова думка, 1966.

6. Тихонов, А.Н. Уравнения математической физики / А.Н. Тихонов, А.А. Самарский. М.: Наука, 1977.

7. Дмитриев, В.И. Интегральные уравнения в краевых задачах электродинамики / В.И. Дмитриев, Е.В. Захаров. - М.: МГУ, 1987.

8. Иванов, В.Т. Метод расчета электрического поля точечного источника в цилиндрическислоистых средах / В.Т. Иванов, Т.М. Яковлева // Физика Земли. - 1997. - № 10. C. 89-91. \& Computer Software (Bulletin SUSU MMCS), 2019, vol. 12, no. 3, pp. 161-169 
9. Ivanov, V.T. Mathematical Modelling of Electric Fields in Electrochemical Protection Systems in Stratified Media / V.T. Ivanov, T.M. Yakovleva // Russian Journal of Electrochemistry. - 1996. - T. 32, № 10. - C. 1133-1139.

10. Канторович, Л.В. Приближенные методы высшего анализа / Л.В. Канторович, В.И. Крылов. - М.; Л.: Физматгиз, 1962.

Татьяна Михайловна Шамсутдинова, кандидат физико-математических наук, доцент, кафедра «Информатика и информационные технологии», Башкирский государственный аграрный университет (г. Уфа, Российская Федерация), tsham@rambler.ru.

Поступила в редакиию 12 февраля 2019 г. 